\title{
Effect of row spacing and seeding rate on baby corn production
}

\section{Efeito de diferentes espaçamentos e densidades de semeadura no cultivo do minimilho}

\author{
André Augusto Favaretto Lucianetti ${ }^{1 *}$; Silvestre Bellettini ${ }^{2}$
}

\section{Highlights:}

Row spacing had the greatest effect on characteristics.

Ear size characteristics were affected by rainfall distribution.

The number of ears harvested per hectare increased as seeding rate increased.

\begin{abstract}
Baby corn is the female green ear of the corn plant harvested before fertilization and its cultivation is a profitable alternative for small farms. The objective of this study was to evaluate the effect of row spacing $(0.5,0.6,0.7,0.8$ and $0.9 \mathrm{~m})$ and seeding rate $(13,15,17$ plants per meter) on baby corn production. The study was conducted at State University of Northern Paraná, Luiz Meneghel Campus, southern Brazil with a $5 \times 3$ factorial scheme (spacing, density) arranged in a randomized block design with four replications. Corn hybrid AG1051 was grown in 5-m long and $6.5-\mathrm{m}$ wide plots. The yield components evaluated were stalk diameter, length and diameter of the unhusked and husked ear, shape index, unhusked yield, husked yield, and marketable yield. Stalk diameter and ear size were significantly affected by row spacing. Ears were not perfectly cylindrical. Baby corn yield was not affected by either row spacing or planting density.
\end{abstract}

Key words: Canned. Spatial distribution. Plant population. Zea mays L.

\section{Resumo}

O minimilho é o nome dado às inflorescências femininas da planta de milho, colhidas antes da fertilização, sendo seu cultivo uma alternativa rentável para pequenas propriedades. Objetivou-se avaliar diferentes espaçamentos $(0,5 ; 0,6 ; 0,7 ; 0,8$ e $0,9 \mathrm{~m})$ entrelinhas e densidades de semeadura $(13,15$ e 17 plantas por metro) de minimilho. O estudo foi conduzido na Universidade Estadual do Norte do Paraná, Campus Luiz Meneghel, com delineamento experimental em blocos ao acaso em esquema fatorial 5 x 3 (espaçamento; densidade) com quatro repetições. As parcelas experimentais compreendiam cinco metros de comprimento por seis metros e meio de largura, o cultivar escolhido de milho híbrido foi o AG1051. As características avaliadas da cultura foram diâmetro do caule, comprimento da espiga com e sem palha, diâmetro da espiga com e sem palha, índice de formato da espiga, produtividade com palha, produtividade sem palha e produtividade padrão indústria. O diâmetro do colmo e o tamanho de espigas apresentaram característica quadrática para o espaçamento. As espigas não apresentaram formato perfeitamente cilíndrico. A produtividade do minimilho não foi afetada pelos espaçamentos e densidades. Palavras-chave: Conserva. Distribuição espacial. População de plantas. Zea mays L.

' Discente do Curso de Mestrado do Programa de Pós-Graduação em Agronomia, Universidade Estadual do Norte do Paraná, Campus Luiz Meneghel, UENP, CLM, Bandeirantes, PR, Brasil. E-mail: andrelucianetti@gmail.com

2 Prof. Dr., Curso de Graduação em Agronomia e Prof., Curso de Mestrado do Programa de Pós-Graduação em Agronomia, UENP, CLM, Bandeirantes, PR, Brasil. E-mail: bellettini@uenp.edu.br

Author for correspondence 


\section{Introduction}

Baby corn is the female inflorescence of immature corn plants harvested before fertilization within two days of silk emergence (Pereira et al., 2009). Because of its miniature size, consumers think that it grows from dwarf corn plants, but they are simply immature ears from regular-sized corn plants (Miles \& Zenz, 2000).

There are no commercial cultivars developed specifically for baby corn production in Brazil; however, normal, sweet, and popcorn varieties produce good yields (Pereira, Gama, \& Furtado, 1998).

Specialty varieties of corn have been developed through breeding specifically for baby corn production in countries such as the United States, Thailand, and India, all of which tend to produce more ears per plant than other common corn varieties. In addition, ear quality is an important criterion when selecting a baby corn variety because consumers are first attracted to ear appearance (Galinat \& Lin, 1988; Miles \& Zenz, 2000; Pattar \& Deshpande, 2019).

The resistance to stalk lodging and breakage is another desirable characteristic of cultivars used for baby corn production. The usual stand density is 150,000 to 200,000 plants per hectare, which corresponds to 2-3 times the planting density for grain crop, leading to thinner, weaker stalks. The optimal row spacing to facilitate cultivation, management, and harvest, which are all done by hand, is $0.8 \mathrm{~m}$. At this spacing, the density per linear meter is 13 to 17 seeds (Pereira et al., 1998; Lana, Guerra, Espindola, \& Araújo, 2012).

Corn is more sensitive to variations in plant density than other members of the grass family. High densities stimulate apical dominance. In dense stands, the amount of solar radiation reaching the apical meristems is smaller, and the increased auxin accumulation stimulates internode elongation, increasing plant height and ear insertion height. In addition, the increase in population size also results in increased intraspecific competition for water, light, and nutrients, reducing the availability of photoassimilates for maintaining vegetative growth, resulting in weakened root and stalk tissues. These traits are affected by the increased plant density, making individuals more prone to stalk lodging and breakage (Sangoi, 2000; Sangoi \& Salvador, 1996; Sangoi, Almeida, Silva, \& Argenta, 2002; Argenta, Silva, \& Sangoi, 2001).

Early hybrid cultivars (super-early hybrids) generally have smaller leaves, shorter stature, and less mutual shading, allowing for closer row spacing and higher planting densities (Sangoi, 2000).

Baby corn is generally harvested $50-70$ days after sowing depending on weather conditions and planting date, which may vary from region to region and directly affect the growth cycle and harvest. Additionally, post-harvest management includes numerous operations because baby corn can be consumed fresh or canned, requiring a number of practices to retain the quality of the produce (Pereira et al., 2009; Santos, Pereira, \& Tomé, 2001).

Baby corn adds a special, gourmet touch to many dishes and salads and can be served raw with other vegetables or included in any stir-fry dish or stew, added to spaghetti sauce or casserole, a rice and bean dish, topped with olive oil, or as a side dish to pasta (Miles, Zenz, \& Alleman, 1999). Baby corn has a nutritional value similar to that of other vegetables and contains on average $89.1 \%$ water, $0.2 \%$ fat, $1.9 \%$ protein, $8.2 \%$ carbohydrates, and $0.6 \%$ ash. In addition, $100 \mathrm{~g}$ of baby corn contains $86 \mathrm{mg}$ phosphorus, $0.1 \mathrm{mg}$ iron, $64 \mathrm{IU}$ vitamin A, $0.05 \mathrm{mg}$ thiamin, $0.8 \mathrm{mg}$ riboflavin, $11 \mathrm{mg}$ ascorbic acid, and 0.3\% niacin (Pereira et al., 1998).

Baby corn is primarily consumed as a canned food. Its cultivated area has increased with the advent of the canning industry, especially in Asian countries, which are the major exporters of baby corn. However, information on baby corn trade, especially imports and exports, is limited because many producing countries either neglect to report 
baby corn production or lack the data (Pereira et al., 1998). Thailand and China are the world leaders in baby corn production, which also proved successful in countries like Taiwan, Sri Lanka, Myanmar, Zambia, and Zimbabwe. Recently South Africa and India also started cultivation of baby corn, and especially India has seen the emergence of a line of research into baby corn production (Singh, Singh, \& Singh, 2019).

Harvesting the baby corn ear lifts the apical dominance from the plant, usually inducing the production of a second, third, and sometimes fourth ear. The second harvest is more profitable because plants are in full production (Pereira \& Karam, 2008).

Few studies have focused on baby corn production in Brazil and further research aimed at increasing baby corn marketability and yield is needed, especially with respect to seeding rate, topdressing fertilization, and other agricultural practices that help achieve higher yields. Planting density has been shown to significantly affect the number, index, and weight of commercial ears (Pereira, Cruz, \& Alvarenga, 2005).

Marketable ears should be bite size: $4-12 \mathrm{~cm}$ long and 1-2 $\mathrm{cm}$ in diameter, cylindrical in shape with pearly white to light yellow kernels (Santos et al., 2001) and these traits are also affected by planting density.

To provide growers with recommendations for meeting marketable standards and increasing baby corn yield, this study investigated the effect of row spacing and seeding rate on baby corn yield components.

\section{Material and Methods}

The study was conducted in the 2017-18 and 2018-19 crop years at the School Farm of State University of Northern Paraná, Luiz Meneghel Campus (UENP/CLM), Bandeirantes, Paraná,

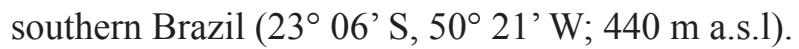

The climate is humid subtropical (Cfa) according to the Köppen classification with the temperature of the three coldest months ranging between $-3{ }^{\circ} \mathrm{C}$ and $18{ }^{\circ} \mathrm{C}$ and the average temperature of the warmest month $>22{ }^{\circ} \mathrm{C}$. The region has a well defined summer and winter season with evenly distributed rainfall and there is no marked dry season (Instituto Agronômico do Paraná [IAPAR], 2019).

Before the experiment was initiated, soil samples were collected at a depth of $0-20 \mathrm{~cm}$ for soil analysis. Based on soil test results, lime was added at 1.3 ton.ha $^{-1}$ based on the recommendations by Raij, Cantarella, Quaggio and Furlani (1996) for corn crops. Soil parameters for the 2017-18 crop year were: organic matter $(\mathrm{OM}) 18.8(\mathrm{~g} / \mathrm{kg}), \mathrm{pH}$ $\mathrm{CaCl}_{2} 4.9$, P (Mehlich) $21.4\left(\mathrm{mg} / \mathrm{dm}^{3}\right), \mathrm{K} 0.43, \mathrm{Ca}$

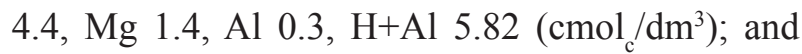
for the 2018-2019 crop year were: organic matter (OM) $24.2(\mathrm{~g} / \mathrm{kg}), \mathrm{pH} \mathrm{CaCl}$ 5.0, P (Mehlich) 38.5 $\left(\mathrm{mg} / \mathrm{dm}^{3}\right), \mathrm{K}$ 0.9, $\mathrm{Ca} 4.2, \mathrm{Mg} 1.5, \mathrm{Al} 0.0, \mathrm{H}+\mathrm{Al} 4.91$ $\left(\mathrm{cmol}_{\mathrm{c}} / \mathrm{dm}^{3}\right)$.

Total precipitation, mean temperatures, and average relative humidity recorded during the experimental period in the 2017-18 and 2018-19 crop years are shown in Figure 1.

The trial was a $5 \times 3$ factorial scheme arranged in a randomized complete block design with five row spacings $(0.5,0.6,0.7,0.8,0.9 \mathrm{~m})$ and three seeding rates $(13,15,17$ plants/meter) with four replications. Plant density per hectare is determined by row spacing and seeding rate as follows: $0.5 \times$ 13:260,000 plants/ha, $0.5 \times 15: 300,000$ plants/ha, $0.5 \times 17: 340,000$ plants/ha, $0.6 \times 13: 216,666$ plants/ ha, $0.6 \times 15: 250,000$ plants/ha, $0.6 \times 17: 283,333$ plants/ha, $0.7 \times 13: 185,714$ plants/ha, $0.7 \times$ 15:214,285 plants/ha, $0.7 \times 17: 242,857 \mathrm{plants} / \mathrm{ha}$, $0.8 \times 13: 162,500$ plants/ha, $0.8 \times 15: 187,500$ plants/ ha, $0.8 \times 17: 212,500$ plants/ha, $0.9 \times 13: 144,444$ plants/ha, $0.9 \times 15: 166,666$ plants/ha, and $0.9 \times$ 17:188,888 plants/ha. Cultivar Agroceres AG1051 (green corn) was grown in the two crop years. Each plot consisted of six sowing rows with data collected 
from the four middle rows. Seeds were treated with imidacloprid + thiodicarb (Cropstar 0.35 L/60,000 seeds) for control of soil insects, including sucking and chewing pests such as the green-belly stink bug and corn-stalk borer.

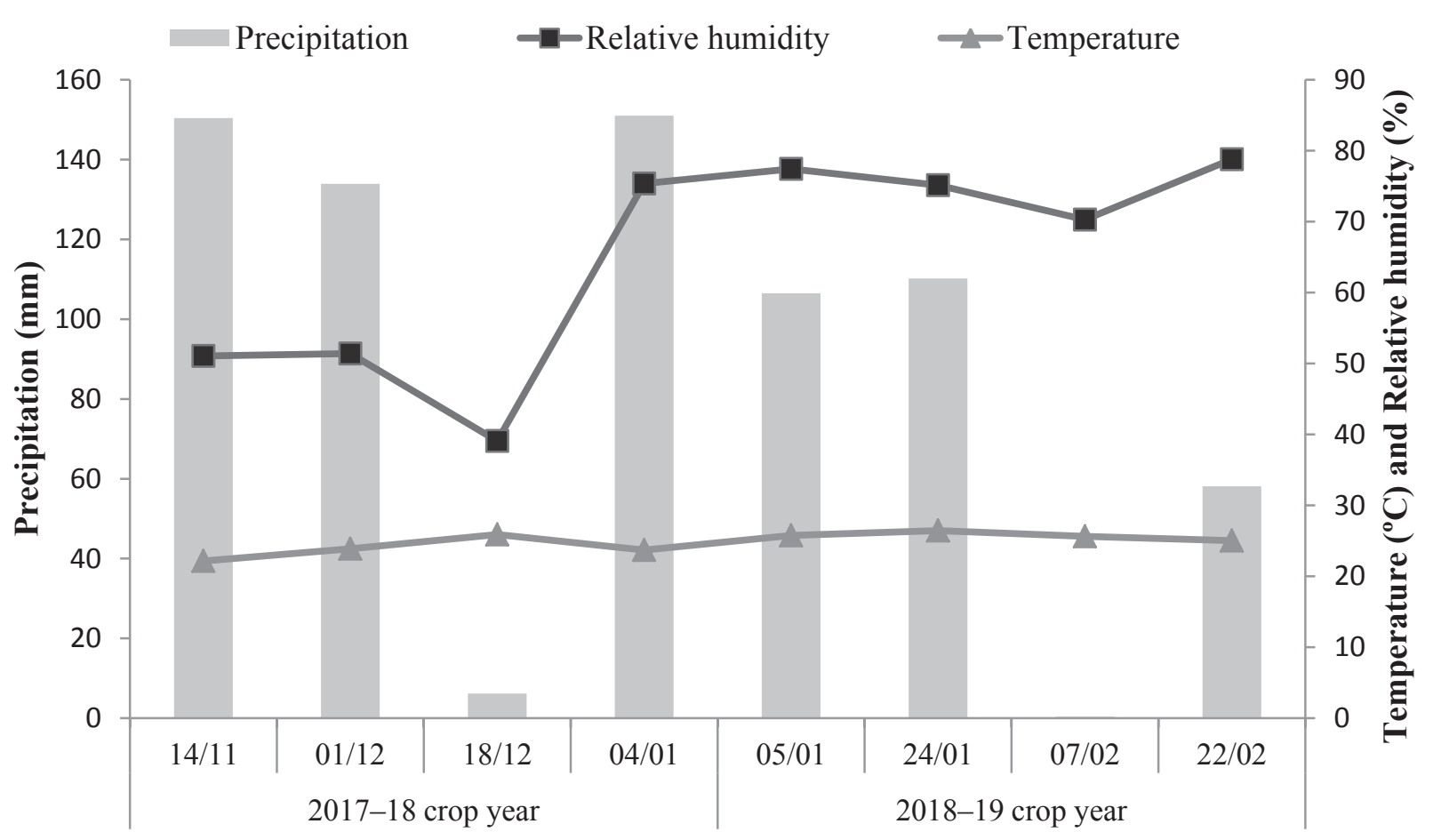

Figure 1. Mean precipitation, temperature, and relative humidity for the 2017-18 and 2018-19 crop years. Bandeirantes, state of Paraná.

Seeds were direct seeded with a wooden hand push seeder fitted with a metering device to place the seeds accurately and uniformly at the desired planting densities in the soil; the seed rate with a safety margin was 20 seeds per meter.

Seedling emergence occurred on 29/10/2017 for the 2017-18 crop year and 20/12/2018 for the 2018-19 crop year. At seven days after emergence, the seedlings were thinned to the desired planting densities. Preplant fertilizer (10-15-15, N-P-K) was applied at a rate of $255 \mathrm{~kg} / \mathrm{ha}$, whereas urea was sidedressed at a rate of $100 \mathrm{~kg} / \mathrm{ha}$ from V4 to V6.

Weeds were managed with applications of atrazine (Primóleo 5.0 L/ha) for broadleaf weeds and tembotrione (Soberan $0.24 \mathrm{~L} / \mathrm{ha}$ ) for grassy weeds, starting soon after weed emergence.
Caterpillar control was achieved with applications of lufenuron (Match 0.3 L/ha) + methomyl (Lannate $0.6 \mathrm{~L} / \mathrm{ha}), \lambda$-cyhalothrin + chlorantraniliprole (Ampligo $0.15 \mathrm{~L} / \mathrm{ha}$ ), and triflumuron (Certero $0.1 \mathrm{~L} / \mathrm{ha}$ ) + zeta-cypermethrin (Mustang 0.2 L/ ha). Insects were controlled with acetamiprid + bifenthrin (Sperto $0.12 \mathrm{~kg} / \mathrm{ha}$ ), imidacloprid + bifenthrin (Galil $0.4 \mathrm{~L} / \mathrm{ha}$ ), and thiamethoxan + $\lambda$-cyhalothrin (Engeo Pleno S 0.25 L/ha).

Because a single baby corn planting may be harvested many times, ears were harvested on $04 / 01 / 2018$ and $11 / 01 / 2018$ in the $2017-18$ crop year and 18/02/2019 and 22/02/2019 in the 2018-19 crop year.

The following yield components were recorded: stalk diameter, diameter of the unhusked and 
husked ear, length of the unhusked and husked ear, shape index, unhusked and husked ear yield, and marketable yield.

Stalk diameter was measured at $1 \mathrm{~cm}$ from the soil in 10 plants from the middle rows at 15,30 , and 60 days after seedling emergence.

The diameter, length, and fresh weight of the unhusked and husked ears were measured from 10 ears per plot randomly harvested from 10 middlerow plants.

Ears were harvested and ear size was measured and recorded, and fresh weight was measured to determine unhusked ear yield $(\mathrm{kg} / \mathrm{ha})$; ears were then husked, and fresh weight was measured to determine husked ear yield $(\mathrm{kg} / \mathrm{ha})$. Husked ears were categorized as marketable $(0.6-1.5 \mathrm{~cm}$ in diameter and $4-12 \mathrm{~cm}$ in length) or unmarketable according to Santos et al. (2001) and had their yield converted to $\mathrm{kg} / \mathrm{ha}$.

Because husked ears are slightly tapered and marketable ears are as nearly cylindrical in shape as possible, we used the shape index proposed by Lima and Athanázio (2008). The shape index (SI) was calculated using the formula $\mathrm{SI}=\mathrm{AV} / \mathrm{OV}$, where $\mathrm{AV}=$ actual volume and $\mathrm{OV}=$ optimum volume. The actual volume was determined by water displacement using a $250-\mathrm{mL}$ beaker. The optimum volume was estimated by the formula for the volume of a cylinder, and shape index values close to 1 indicate a cylindrical ear and those close to 0.5 a tapering ear.

The data were analyzed separately for each crop year using the analysis of variance (ANOVA) F-test. When the interaction between row spacing and planting density was significant, the effect of row spacing was evaluated separately for each planting density. When probability values were less than or equal to 0.05 by the F-test, means were separated using Tukey's multiple comparison test for planting density and linear and quadratic regression analysis for row spacing. When both linear and quadratic regression models were significant $(\mathrm{p}<$ $0.05)$, the equation with the highest coefficient of determination $\left(\mathrm{R}^{2}\right)$ was selected.

\section{Results and Discussion}

Stalk diameter at 30 days after emergence was significantly affected by the row spacing $\times$ planting density interaction in the 2017-18 crop year. Conversely, neither the row spacing $\times$ planting density interaction nor the main effects reached significance in the 2018-19 crop year. In addition, stalk diameter at 60 days was significantly affected by row spacing in the two crop years (Table 1).

Stalk diameter decreased as row spacing decreased and plant density increased (Figure 2), consistent with earlier findings of Dourado et al. (2003) who reported that a reduction in row spacing resulted in smaller stalk diameter. Calonego, Poleto, Domingues, \& Tiritan (2011) reported that stalk diameter decreased as plant density increased. Increased vegetative growth and internode elongation and reduced stalk diameter are common responses of corn hybrids to increased plant population (Marchão, Brasil, Duarte, Guimarães, \& Gomes, 2005; Kappes et al., 2011).

The maximum stalk diameter is represented by the intersections of the three growth curves (D13, D15, and D17), which was estimated at D13 $=0.87$ and $\mathrm{D} 17=0.79$, indicating that the optimum row spacing for baby corn production is from 0.8 to 0.9 $\mathrm{m}$. Wider row spacing also contributes to the ease of hand harvesting and walking between the rows (Pereira \& Karam, 2008). 


\section{Table 1}

F values for stalk diameter at 15, 30, and 60 days after emergence in the 2017-18 and 2018-19 crop years

\begin{tabular}{lccc}
\hline \multicolumn{4}{c}{ Stalk diameter, 2017-18 } \\
\hline & 15 & 30 & 60 \\
\hline Row spacing (S) & $0.69^{\text {ns }}$ & $13.14^{*}$ & $14.39^{*}$ \\
Planting density (D) & $0.67^{\text {ns }}$ & $1.90^{\text {ns }}$ & $3.09^{\text {ns }}$ \\
S $\times$ D interaction & $0.67^{\text {ns }}$ & $2.43^{*}$ & $0.71^{\text {ns }}$ \\
\hline CV\% & 9.71 & 4.69 & 5.87 \\
\hline \multicolumn{4}{c}{ Stalk diameter, 2018-19 } \\
\hline Row spacing (S) & 15 & 30 & 60 \\
Planting density (D) & $0.39^{\text {ns }}$ & $2.11^{\text {ns }}$ & $3.34^{*}$ \\
S $\times$ D interaction & $0.002^{\text {ns }}$ & $0.01^{\text {ns }}$ & $1.08^{\text {ns }}$ \\
\hline CV\% & $0.81^{\text {ns }}$ & $0.68^{\text {ns }}$ & $0.87^{\text {ns }}$ \\
\hline
\end{tabular}

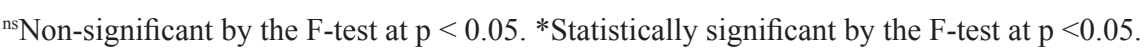

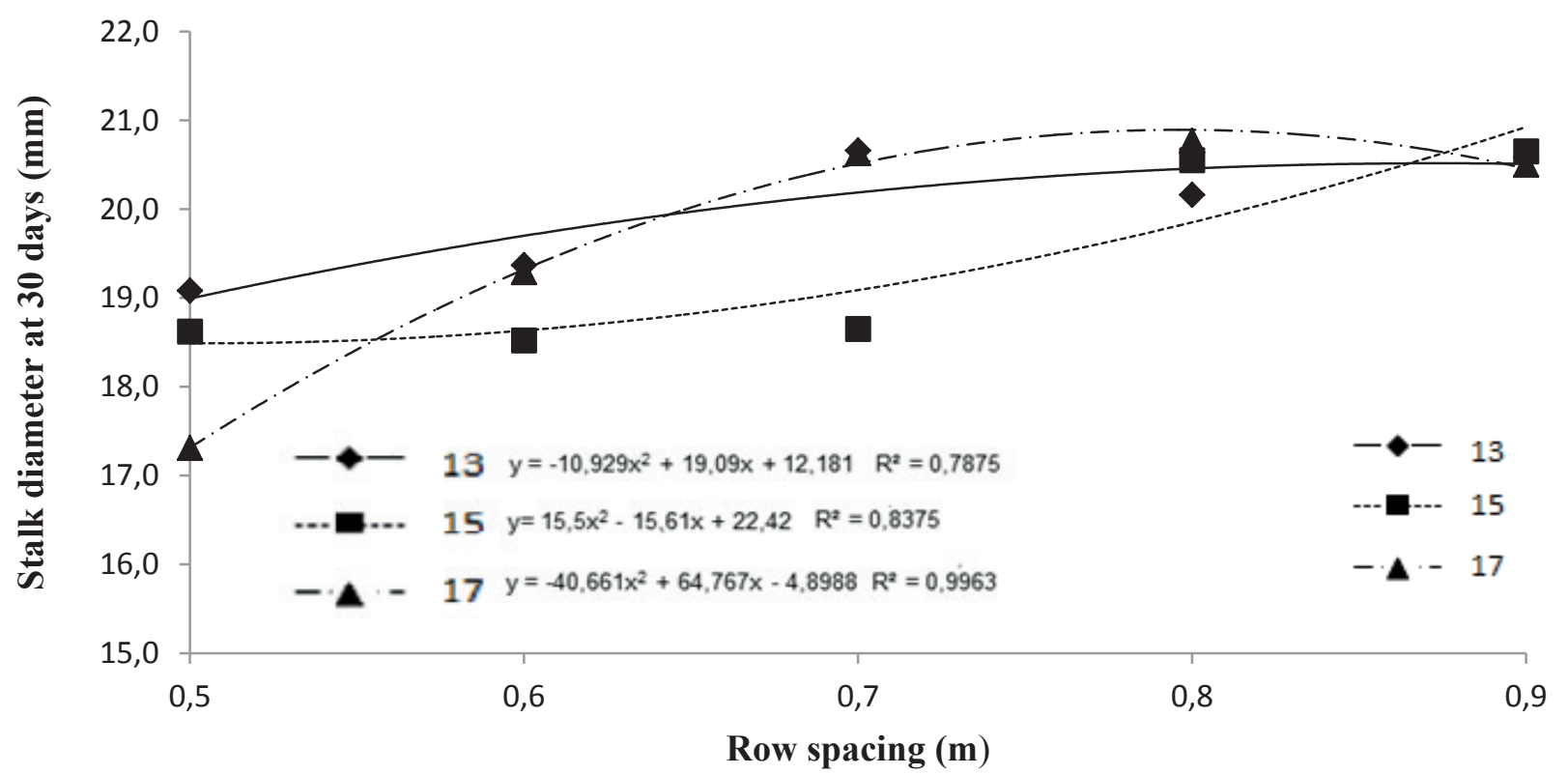

Figure 2. Row spacing $\times$ planting density interaction for stalk diameter at 30 days in the 2017-18 crop year.

Mean stalk diameter at 30 days ranged from 10.7 to $19.97 \mathrm{~mm}$ in the 2017-18 crop year and was not significantly affected by planting density, contrary to the findings of Marchão et al. (2005) and Kappes et al. (2011) who reported that stalk diameter decreased as plant population increased. According to Hanway (1966), at 30 days the plant reaches the period of rapid elongation and stalk growth when the fifth and sixth internodes elongate to about 1.0 and $2.5 \mathrm{~cm}$, respectively.

Stalk diameter at 60 days was significantly affected by row spacing in the two crop years (Table 1) and coincided with full silking of cultivar AG1051. Figure 3 shows that stalk diameter 
decreased as plant density increased at closer row spacing, consistent with the findings of Demétrio, Fornasieri, Cazetta and Cazzeta (2008), Dourado et al. (2003), and Calonego et al. (2011) who reported an inverse relationship between stalk diameter and plant density.

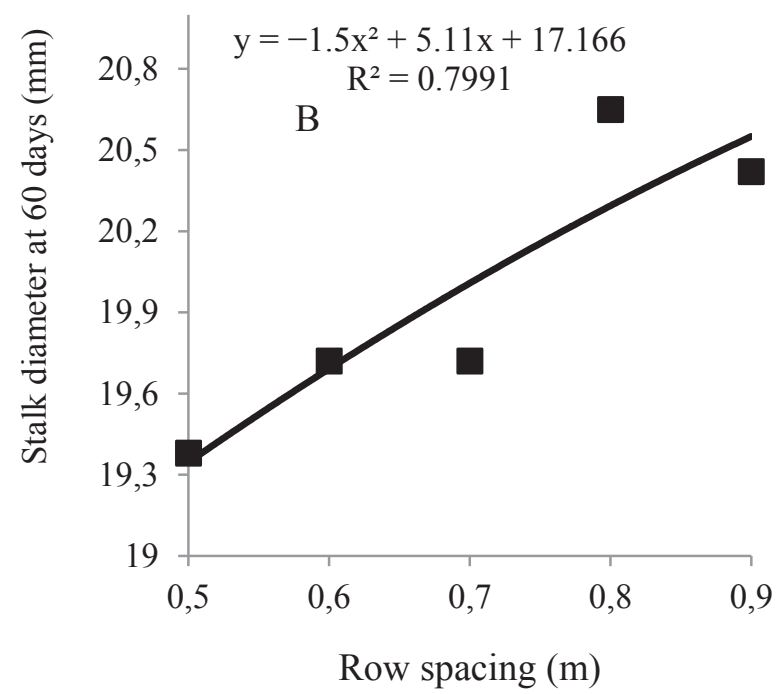

Figure 3. Stalk diameter at 60 days in the (A) 2017-18 and (B) 2018-19 crop years.

Kasperbauer and Karlen (1994) showed that corn seedlings in the higher population density allocated more photosynthate for development of longer stems and longer leaves to increase the probability that the plant would have some photosynthetic area above competing plants. And when a greater fraction of photosynthate was allocated to elongating stems, less remained for root growth, making the plants more prone to lodging.

Previous studies with the same plant populations and various row spacings reported that stalk diameter values were higher in plants grown with closer spacing than in plants grown with wider spacing (Balbinot \& Fleck, 2005; Dourado et al., 2003). In regular, more uniform plant arrangements intraspecific competition for water, light, and nutrients is relaxed, promoting plant growth (Argenta et al., 2001).

Stalk diameter increased as plant population decreased and intraspecific competition is relaxed, resulting in normal plant development and larger stalk diameter. Conversely, increased intraspecific competition stimulates apical dominance, increasing plant height and reducing stalk diameter (Sangoi \& Salvador, 1998; Sangoi, 2000; Dourado et al., 2003).

The diameter and length of the unhusked and husked ears were significantly affected by row spacing in the 2017-18, but not in the 2018-19 crop year (Table 2 and Figure 4).

Ear diameter and length were not significantly affected by seeding rate in the second harvest (2018-19 crop year) because total rainfall was only $253 \mathrm{~mm}$ distributed over 64 days (average of 4.68 $\mathrm{mm} /$ day). Intraspecific competition increases at higher densities reducing ear size, but even though ears were smaller in size because of the very low rainfall levels, they were not significantly smaller than ears from plants grown at lower densities. Total rainfall in the first harvest (2017-18 crop year) was $442 \mathrm{~mm}$, distributed over 68 days for an average of $6.5 \mathrm{~mm} /$ day, well above that of the 2018-19 crop 
year (Figure 1). The seasonal water requirement for grain production is roughly $600 \mathrm{~mm}$ and because time to harvest for baby corn is half that for grain crop, total rainfall was slightly below the expected levels. However, seeding rates for baby corn production are 2-3 times greater than those used for grain production, thus increasing water requirement (Pereira et al., 1998; Magalhães \& Durães, 2006). Dourado et al. (2003) evaluated the effect of row spacing $(0.4$ and $0.8 \mathrm{~m})$, seeding rate $(30,60$, and
90 thousand plants per hectare), and genotype (AG 1051, AG 7575, and DKB 911) and reported that ear length values for hybrid AG 1051 were higher at lower plant densities, whereas ear length values were higher for cultivar AG 1051 at 90,000 plants/ ha compared to hybrid DKB 911 at the $0.8 \mathrm{~m}$ row spacing. This result indicates that cultivar AG 1051 has longer ears than cultivars AG 7575 and DKB 911, which also contributed to the smaller difference in ear length for the 2018-19 crop year.

\section{Table 2}

F values for diameter of the unhusked (DUE) and husked (DHE) ear and length of the unhusked (LUE) and husked (LHE) ear in the 2017-18 and 2018-19 crop years

\begin{tabular}{|c|c|c|c|c|}
\hline \multicolumn{5}{|c|}{ 2017-18 crop year } \\
\hline & DUE & DHE & LUE & LHE \\
\hline Row spacing (S) & $4.06^{*}$ & $4.91^{*}$ & $9.80^{*}$ & $8.50^{*}$ \\
\hline Planting density (D) & $0.014^{\mathrm{ns}}$ & $1.77^{\mathrm{ns}}$ & $2.30^{\mathrm{ns}}$ & $1.13^{\mathrm{ns}}$ \\
\hline $\mathrm{S} \times \mathrm{D}$ interaction & $1.68^{\mathrm{ns}}$ & $0.74^{\mathrm{ns}}$ & $1.32^{\mathrm{ns}}$ & $1.54^{\mathrm{ns}}$ \\
\hline $\mathrm{CV} \%$ & 7.52 & 8.34 & 3.97 & 5.72 \\
\hline \multicolumn{5}{|c|}{ 2018-19 crop year } \\
\hline & DUE & DHE & LUE & LHE \\
\hline Row spacing (S) & $0.69^{\text {ns }}$ & $1.08^{\mathrm{ns}}$ & $1.03^{\mathrm{ns}}$ & $1.78^{\mathrm{ns}}$ \\
\hline Planting density (D) & $0.19^{\mathrm{ns}}$ & $0.22^{\mathrm{ns}}$ & $1.82^{\mathrm{ns}}$ & $1.48^{\mathrm{ns}}$ \\
\hline $\mathrm{S} \times \mathrm{D}$ interaction & $0.44^{\mathrm{ns}}$ & $0.75^{\text {ns }}$ & $0.56^{\mathrm{ns}}$ & $1.31^{\mathrm{ns}}$ \\
\hline $\mathrm{CV} \%$ & 8.67 & 8.17 & 6.45 & 7.31 \\
\hline
\end{tabular}

${ }^{\mathrm{n}}$ Non-significant by the F-test at $\mathrm{p}<0.05$. ${ }^{*}$ Statistically significant by the F-test at $\mathrm{p}<0.05$.

Figure 4 shows that ear diameter and length in the 2017-18 and 2018-19 crop years increased as row spacing increased and, consequently, plant density (plants/ha) decreased (Figure 4). Dourado et al. (2003) evaluated two row spacings ( 0.4 and $0.8 \mathrm{~m})$, three seeding rate $(30,60$, and 90 thousand plants/ha), and three genotypes (AG 1051, AG 7575, and DKB 911) and found that ear length values for cultivar AG 1051 were higher at lower seeding rates regardless of row spacing, but were smaller in plants grown with $0.8 \mathrm{~m}$ spacing at higher seeding rates compared to cultivar AG 7575. Calonego et al. (2011) reported that ear size and number of kernels per ear were highest in plants grown with $0.9 \mathrm{~m}$ row spacing. 

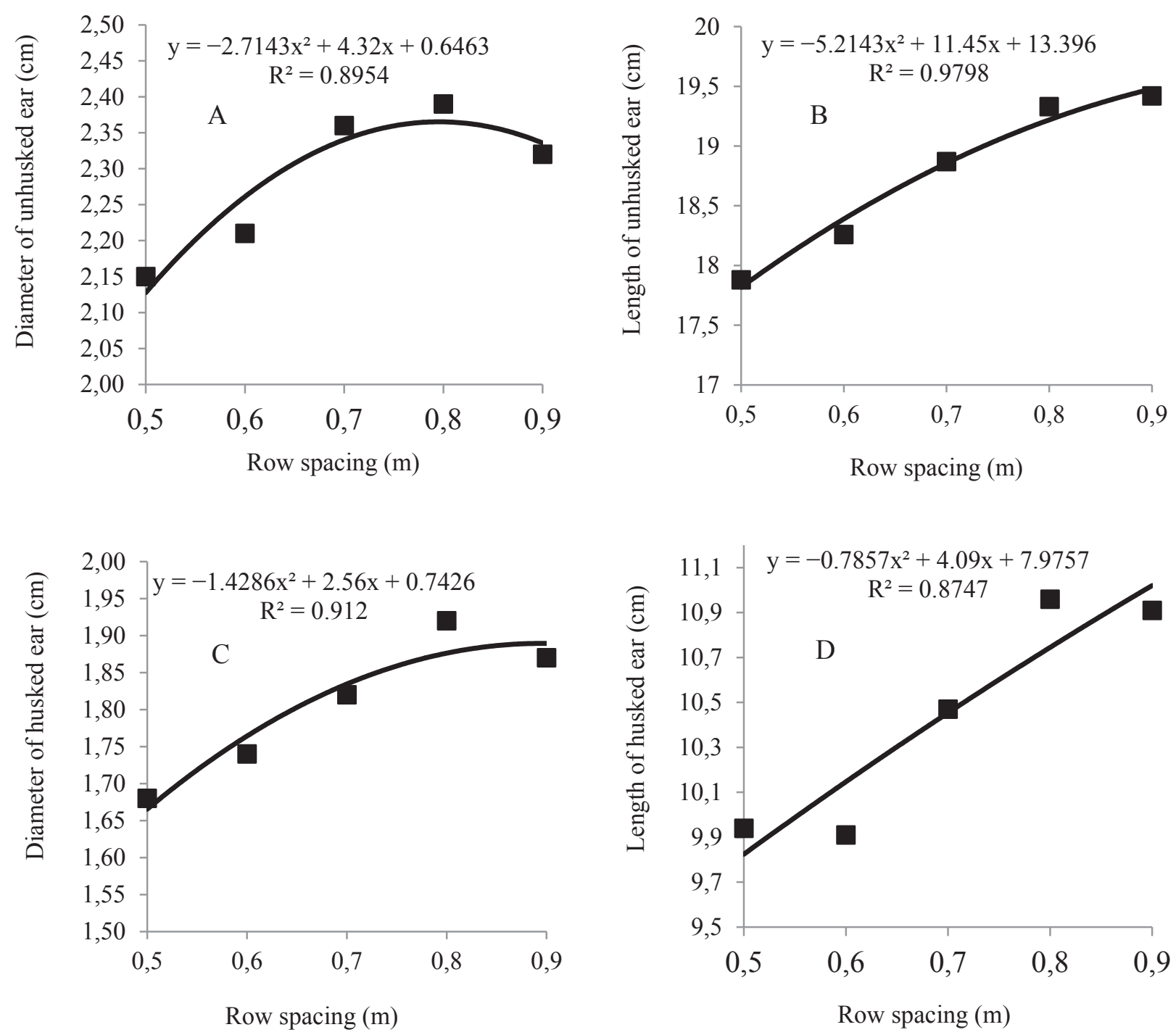

Figure 4. Effect of row spacing on the diameter of (A) unhusked and (B) husked ears and length of (C) unhusked and (D) husked ears in the 2017-18 crop year.

Marchão et al. (2005) reported that mean values for ear length and diameter, cob diameter, number of kernels per row, and 1.000 kernel weight decreased as plant population increased.

According to Sangoi et al. (2002), intraspecific competition for light, nutrients, and water affects ear ontogeny, especially in higher population densities, which may result in limited carbon and nitrogen supplies, ultimately reducing the number of kernels per ear and 1,000 kernel weight.
Rodrigues, Silva and Mori (2004) evaluated seven baby corn families used for baby corn production and reported values ranging from 6.4 to $8.5 \mathrm{~cm}$ and 1.11 to $1.32 \mathrm{~cm}$ for the length and diameter of the husked ear, respectively, all within the marketable standards but lower than the values for ear size obtained in the current study, which was near the limit of large-sized ears (Santos et al., 2001). 
Almeida, Silva, Negreiros and Barbosa (2005) evaluated different corn cultivars for baby corn production and found significant differences in diameter and length of the husked ear between cultivars. In their study, cultivar AG 2060 produced the largest ears: $9.9 \mathrm{~cm}$ long and $1.5 \mathrm{~cm}$ in diameter.

Rodrigues and Silva (2002) evaluated the yield of single-corn hybrids for baby corn production and found no significant difference in length of the husked ear and diameter of the unhusked and husked ear, but the length of the unhusked ear was significantly different across hybrids.

Vale, Fritsche and Silva (2011) selected corn cultivars suitable for baby corn production and field corn and found statistically significant differences in ear size characteristics (length and diameter) between the cultivars. Conversely, Pereira et al. (2005) reported that ear length was not significantly affected by seeding rate $(150,000,180,000$, and 200,000 plants/ha).
According to Santos et al. (2001), the cobs of baby corn are classified in three classes for the Brazilian market based on the size of the husked ear: small 6-8 $\mathrm{cm}$ long and $1 \mathrm{~cm}$ in diameter, medium $8-10 \mathrm{~cm}$ long and $1.5 \mathrm{~cm}$ in diameter, and large $10-12 \mathrm{~cm}$ long and $2 \mathrm{~cm}$ in diameter. Ears should be cylindrical with pearly white to light yellow kernels. In the Brazilian market, medium-sized ears are preferred. Thus, based on our findings, the 0.5 and $0.6 \mathrm{~m}$ spacing are recommended to supply the Brazilian canning industry, which follows the market preference for medium ears.

The shape index (SI) (Lima \& Athanázio, 2008) was not significantly affected by row spacing or planting density in the 2017-18 and 2018-19 crop years (Table 3 ). In addition, SI values were not equal to 1 in the two crop years (data not shown), indicating that ears were not perfectly cylindrical.

\section{Table 3}

F values for shape index in the 2017-18 and 2018-19 crop years

\begin{tabular}{lcc}
\hline & Shape index & \\
\hline & $2017-18$ & $2018-19$ \\
\hline Row spacing (S) & $2.09^{\text {ns }}$ & $1.19^{\text {ns }}$ \\
Planting density (D) & $0.59^{\text {ns }}$ & $0.07^{\text {ns }}$ \\
S $\times$ D interaction & $0.93^{\text {ns }}$ & $0.56^{\text {ns }}$ \\
\hline CV\% & 13.23 & 9.28 \\
\hline
\end{tabular}

${ }^{n s}$ Non-significant by the F-test at $\mathrm{p}<0.05$. ${ }^{*}$ Statistically significant by the F-test at $\mathrm{p}<0.05$.

Unhusked yield, husked yield, and marketable yield were not significantly affected by row spacing and planting density in the 2017-18 and 2018-19 crop years (Table 4). 
Table 4

F values for unhusked ear yield (UEY), husked ear yield (HEY), and marketable ear yield (MEY) in the 2017-18 and 2018-19 crop years

\begin{tabular}{lccc}
\hline & \multicolumn{2}{c}{$2017-18$ crop year } & MEY \\
\hline Row spacing (S) & UEY & HEY & $0.53^{\text {ns }}$ \\
Planting density (D) & $0.27^{\text {ns }}$ & $0.27^{\text {ns }}$ & $1.60^{\text {ns }}$ \\
S $\times$ D interaction & $1.35^{\text {ns }}$ & $1.35^{\text {ns }}$ & $0.66^{\text {ns }}$ \\
\hline CV\% & $1.50^{\text {ns }}$ & $1.50^{\text {ns }}$ & 17.90 \\
\hline & 14.40 & 14.40 & MEY \\
\hline Row spacing (S) & $2018-19$ crop year & $1.93^{\text {ns }}$ \\
Planting density (D) & HEY & $1.40^{\text {ns }}$ & $0.88^{\text {ns }}$ \\
S $\times$ D interaction & $15.72^{\text {ns }}$ & $0.75^{\text {ns }}$ & $0.85^{\text {ns }}$ \\
\hline CV\% & $0.74^{\text {ns }}$ & $0.99^{\text {ns }}$ & 24.27 \\
\hline
\end{tabular}

${ }^{\mathrm{n}}$ Non-significant by the F-test at $\mathrm{p}<0.05$. $*$ Statistically significant by the F-test at $\mathrm{p}<0.05$.

Remison and Lucas (1982) reported that 1,000 kernel weight, ear diameter, number of kernels per ear, and number of kernels per row decreased as plant population increased, whereas in another study an increase in plant population from 4.5 to 9 plants per $\mathrm{m}^{2}$ resulted in a grain yield increase of 4.5 tons/ha (Bavec \& Bavec, 2002).

A decrease in ear size is not a concern for baby corn production because ears are generally harvested just at silk emergence, but the increase in plant population results in more ears per hectare, which may increase baby corn yield.

Rodrigues, Silva and Mori (2003) evaluated two planting densities $(55,000$ plants/ha and 110,000 plants/ha) and found that unhusked and husked yields were highest in the higher population density, whereas Pereira et al. (2005) reported that the weight of the unhusked and husked ear was not significantly affected by seeding rate $(150,000$, 180,000, and 200,000 plants/ha).

Golada, Sharma and Nepalia (2017) investigated the effect of crop spacing $(45 \times 20,60 \times 15$, and $90 \times 10 \mathrm{~cm})$, nitrogen levels $(60,90$, and $120 \mathrm{~kg} /$ ha), and plant growth regulators (control, NAA, and mepiquat chloride) on baby corn yield and found that yields were highest at the $60 \times 15 \mathrm{~cm}$ spacing.

In the current study, baby corn yield was not affected either by row spacing or planting density, which may be attributed to shading in higher densities. Hashemi Dezfouli and Herbert (1992) reported that photosynthetically active radiation decreased by $20 \%$ when plant density increased from 3 to 7.5 plants per $\mathrm{m}^{2}$ (7.5 plants $/ \mathrm{m}^{2}=75,000$ plants/ha). Because plant populations in our study ranged from 160,000 to 340,000 plants/ha, shading may have had a stronger effect than in the study by Hashemi Dezfouli and Herbert (1992).

The number of ears harvested per hectare was highest at the $0.5 \mathrm{~m}$ row spacing $(\sim 172,000$ ears/ ha) and lowest at the $0.9 \mathrm{~m}$ spacing $(154,000$ ears harvested per/ha) (Figure 5). This result indicates that even though there was no significant difference in the number of ears between planting densities, the number of ears harvested per hectare was significantly affected by row spacing. 


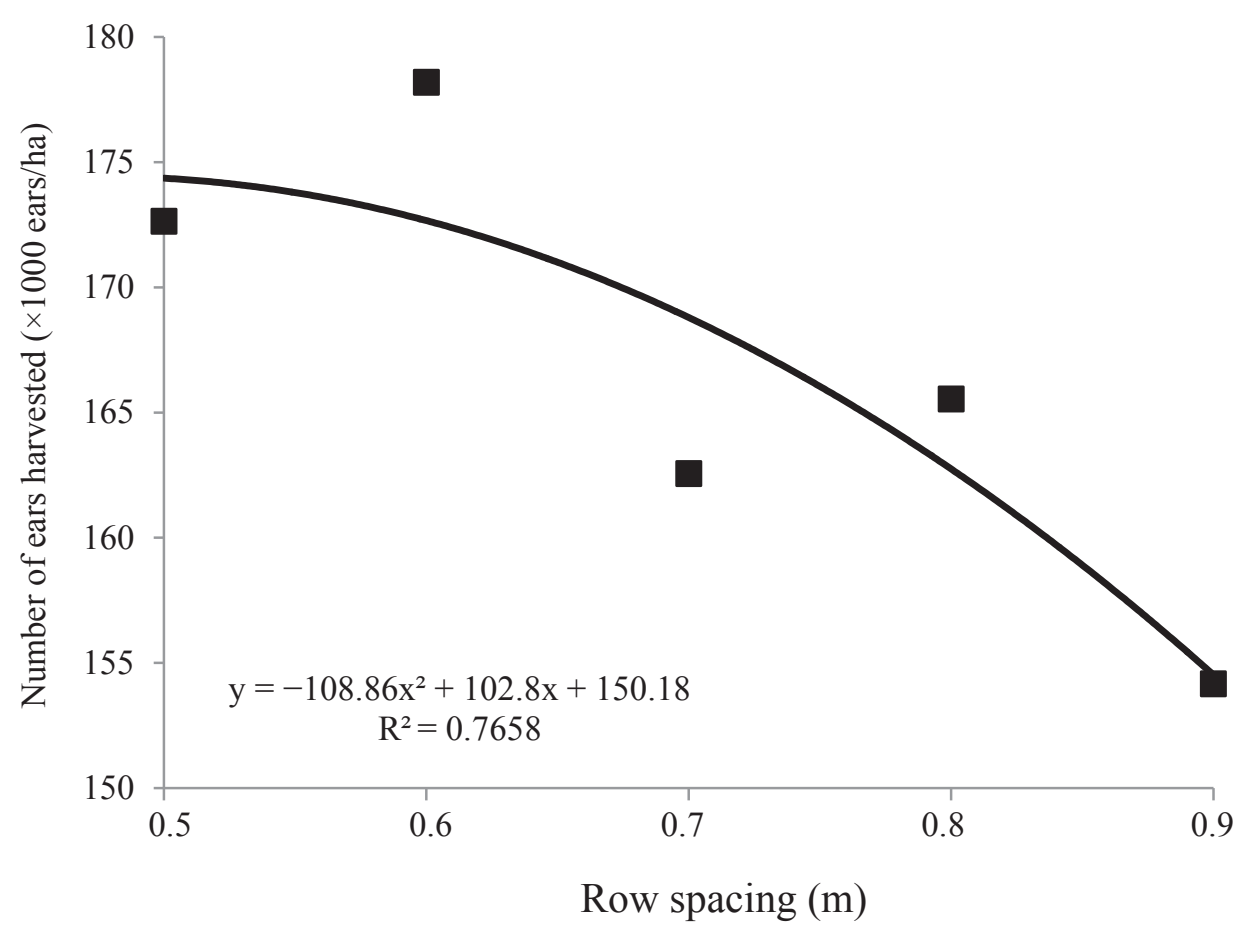

Figure 5. Mean number of ears harvested per hectare in the 2017-18 and 2018-19 crop years.

One hypothesis for this finding is that even though the closer row spacing had higher population densities resulting in more ears per hectare, fresh weight per ear was lower, contributing to the lack of difference in mean ear weight between plant densities.

Baby corn yield components were not significantly affected by either row spacing or planting density (Table 4), indicating that baby corn can be grown at different spacings without affecting yield.

The 0.5 and $0.6 \mathrm{~m}$ spacing are recommended for producing marketable ears by size. However, they did not produce significant increases in yield compared to the $0.7-0.9 \mathrm{~m}$ spacing, even though plants grown at close spacing had higher population densities.

The increase in plant population, despite the increases in yield, generally negatively affects yield components regardless of the growth cycle of the hybrid and is usually associated with an increase in intraspecific competition (Dourado et al., 2003; Flesch \& Vieira, 2004; Sangoi, 2000). In our study, yield components were greatly affected and did not provide the desired increase in yield as plant population increased.

Previous reports have consistently demonstrated that corn stalk diameter decreases as plant population increases (Marchão et al., 2005; Kappes et al., 2011). Thinner stalks are more susceptible to lodging and breakage because plant population levels that are too high cause the corn plant to become tall and thin, significantly reducing the physical strength of the corn stalk and increasing the potential for stalk lodging (Argenta et al., 2001). Brachtvogel, Pereira, Cruz and Bicudo (2009) evaluated corn yield at 30,000, 45,000, 60,000, 75,000, 90,000, and 105,000 plants/ha and found a marked increase in the percentage of lodged and broken plants as plant population increased. 
This study was not designed to evaluate stalk lodging and breakage, but we noticed that lodging propensity was higher, and harvesting time increased as a result of delayed silk emergence at the 0.5 and $0.6 \mathrm{~m}$ spacing compared to the $0.7,0.8$, and $0.9 \mathrm{~m}$ spacing.

According to Pereira and Karam (2008), baby corn grown with 0.8 spacing is easier to manage and hand-harvest.

\section{Conclusions}

Stalk diameter and ear size were affected by row spacing.

Ears were not perfectly cylindrical.

Baby corn yield was not affected by row spacing and planting density.

\section{Acknowledgements}

This study received financial support from the Coordination for the Improvement of Higher Education Personnel (CAPES) Financing Code 001.

\section{References}

Almeida, I. P. C., Silva, P. S. L., Negreiros, M. Z., \& Barbosa, Z. (2005). Baby corn, green ear, and grain yield of corn cultivars. Horticultura Brasileira, 23(4), 960-964. doi: 10.1590/S0102-05362005000400020

Argenta, G., Silva, P. R. F., \& Sangoi, L. (2001). Arranjo de plantas em milho: análise do estado-da-arte. Ciência Rural, 31(6), 1075-1084. doi: 10.1590/ S0103-

Balbinot,A.A., Jr., \& Fleck, N. G. (2005). Competitividade de dois genótipos de milho (Zea mays) com plantas daninhas sob diferentes espaçamentos entre fileiras. Planta Daninha, 23(3), 415-421. doi: 10. 1590/ S0100-83582005000300004

Bavec, F., \& Bavec, M. (2002). Effects of plant population on leaf area index, cob characteristics and grain yield of early maturing maize cultivars (FAO 100-400). European Journal of Agronomy, 16(2), 151-159. doi: 10.1016/S1161-0301(01)00126-5
Brachtvogel, E. L., Pereira, F. R. S., Cruz, S. C. S., \& Bicudo, S. J. (2009). Densidades populacionais de milho em arranjos espaciais convencional e equidistante entre plantas. Ciência Rural, 39(8), 23342339. doi: 10.1590/S0103-84782009005000193

Calonego, J. C., Poleto, L. C., Domingues, F. N., \& Tiritan, C. S. (2011). Produtividade e crescimento de milho em diferentes arranjos de plantas. Revista Agrarian, 4(12), 84-90. Recuperado de https://ojs. ufgd. edu.br/index.php/agrarian/article/view/699/

Demétrio, C. S., Fornasieri, D., Fº, Cazetta, J. O., \& Cazetta, D. A. (2008). Desempenho de híbridos de milho submetidos a diferentes espaçamentos e densidades populacionais. Pesquisa Agropecuária Brasileira, 43(12), 1691-1697. doi: 10.1590/S0100204X2008001200008

Dourado, D., Neto, Palhares, M., Viera, P. A., Manfron, P. A., Medeiros, S. L. P., \& Romano, M. R. (2003). Efeito da população de plantas e do espaçamento sobre a produtividade de milho. Revista Brasileira de Milho e Sorgo, 2(3), 63-77. doi: 10.18512/19806477/rbms.v2n03p\%25p

Flesch, R. D., \& Vieira, L. C. (2004). Espaçamentos e densidades de milho com diferentes ciclos no oeste de Santa Catarina, Brasil. Ciência Rural, 34(1), 2531. doi: 10.1590/S0103-84782004000100005

Galinat, W. C., \& Lin, B. Y. (1988). Baby corn: production in Taiwan and future outlook for production in the United States. Economic Botany, 42(1), 132-134. Recuperado de https://www.jstor.org/stable/425 5054

Golada, S., Sharma, G. L., \& Nepalia, V. (2017). Effect of spacing, nitrogen and growth regulators on yield and nutrient uptake by baby corn (Zea mays L.). Annals of Plant and Soil Research, 19(2), 148-153. Recuperado de http://gkvsociety.com/control/uploads/ SHANKAR\%20LAL\%20GOLADA,\%20G.L.\%20 SHARMA\%20AND\%20V.\%20NEPALIA.pdf

Hanway, J. J. (1966). How a corn plant develops. Iowa State University of Science and Technology, (48), 1-17. Recuperado de http://lib.dr.iastate.edu/ specialreports $/ 38$

Hashemi Dezfouli, A., \& Herbert, S. J. (1992). Intensifying plant density response of corn with artificial shade. Agronomy Journal, 84(4), 547-551. doi: 10.2134/agronj1992.00021962008400040001x

Instituto Agronômico do Paraná (2019). Cartas climáticas do Paraná. Recuperado de http://www.iapar.br/ modules/conteudo/conteudo.php?conteudo=597 
Kappes, C., Andrade, J. A. C., Arf, O., Oliveira, A. C., Arf, M. V., \& Ferreira, J. P. (2011). Desempenho de híbridos de milho em diferentes arranjos espaciais de plantas. Bragantia, 70(2), 334-343. doi: 10.1590/ S0006-87052011000200012

Kasperbauer, M. J., \& Karlen, D. L. (1994). Plant spacing and reflected far-red light effects on phytocrome-regulated phtotosynthate allocation in corn seedlings. Crop Science, 34(6), 1564-1569. doi: 10.2135/ cropsci1994.0011183X003400060027x

Lana, L. O., Guerra, J. G. M., Espindola, J. A. A., \& Araújo, E. S. (2012). Avaliação de genótipos de milho com dupla aptidão para produção de minimilho e biomassa para adubação verde. (Boletim de Pesquisa e Desenvolvimento). Seropédica: EMBRAPA Agrobiologia.

Lima, C. B., \& Athanázio, J. C. (2008). Caracterização comercial de raízes de cenoura de seis ciclos de seleção da variedade 'Londrina'. Semina: Ciências Agrárias, 29(3), 507-514. Recuperado de https:// www.redalyc.org/articulo.oa?id=445744089004

Magalhães, P. C., \& Durães, F. O. M. (2006). Fisiologia da produção de milho. (Circular Técnica, 76). Sete Lagoas: EMBRAPA Milho e Sorgo.

Marchão, R. L., Brasil, E. M., Duarte, J. B., Guimarães, C. M., \& Gomes, J. A. (2005). Densidades de plantas e características agronômicas de híbridos de milho sob espaçamento reduzido em milho. Pesquisa Agropecuária Tropical, 35(2), 93-101. Recuperado de https://www.redalyc.org/articulo.oa? $\mathrm{id}=253020145005$

Miles, C., \& Zenz, L. (2000). Baby corn. farming west of the cascades. Washington: Washington State University.

Miles, C., Zenz, L., \& Alleman, G. (1999). Baby corn: A flavorful, appealing addition to salads, pasta, soups and other favorite dishes. Washington State: University Cooperative Extension King County. Recuperado de https://agsyst.wsu.edu

Pattar, V. K., \& Desphande, S. K. (2019). Combining ability studies for yield and quality traits in baby corn (Zea mays L.). Journal of Pharmacognosy and Phytochemistry, 8(4), 1116-1119. Recuperado de http://www.phytojournal.com/archives/2019/ vol8issue4/PartS/8-2-484-164.pdf

Pereira, I. A., Fo., Cruz, J. C., \& Alvarenga, R. C. (2005). Efeito de densidade de semeadura, niveis de nitrogênio e despendoamento sobre a produção de minimilho. (Comunicado Técnico, 119). Sete Lagoas: EMBRAPA Milho e Sorgo.
Pereira, I. A., F., Cruz, J. C., Queiroz, V. A. V., Caxito, A. M., Leite, C. E. P., \& Carmo, Z. C. (2009). Avaliação de cultivares de milho visando à produção de minimilho na região norte do estado de Minas Gerais. (Circular Técnica, 131). Sete Lagoas: EMBRAPA Milho e Sorgo.

Pereira, I. A., Fo., Gama, E. E. G., \& Furtado, A. A. L. (1998). Produção do minimilho .(Comunicado Técnico, 7). Sete Lagoas: EMBRAPA Milho e Sorgo.

Pereira, I. A., Fº., \& Karam, D. (2008). Coleção plantar minimilho: a cultura do minimilho. Brasília: EMBRAPA Informação Tecnológica.

Raij, B. V., Cantarella, H., Quaggio, J. A., \& Furlani, A. M. C. (1996). Recomendações de adubação e calagem para o Estado de São Paulo. (Boletim, 100). (2a ed.). Campinas: Fundação IAC.

Remison, S. U., \& Lucas, E. O. (1982). Effects of planting density on leaf area and productivity of two maize cultivars in Nigeria. Experimental Agriculture, 18(1), 93-100. doi: 10.1017/S0014479700013478

Rodrigues, L. R. F., \& Silva, N. (2002). Combining ability in baby corn inbred lines (Zea mays L.). Crop Breeding and Applied Biotechnology, 2(3), 361368. Recuperado de http://www.sbmp.org.br/cbab/ siscbab/uploads/c8128f42-5220-1dd7.pdf

Rodrigues, L. R. F., Silva, N., \& Mori, E. S. (2003). Baby corn single-cross hybrids yield in two plant densities. Crop Breeding and Applied Biotechnology, 3(3), 177-184. Recuperado de https://pdfs.semanticscholar.org/7ba0/f5a372d81c 3a49c1bb609e2d5dbbcd497f4b.pdf

Rodrigues, L. R. F., Silva, N., \& Mori, E. S. (2004). Avaliação de sete famílias $S_{2}$ prolíficas de minimilho para a produção de híbridos. Bragantia, 63(1), 3138. doi: 10.1590/S0006-87052004000100004

Sangoi, L. (2000). Understanding plant density effects on maize growth and development: an important issue to maximize grain yield. Ciência Rural, 31(1), 159168. doi: 10.1590/S0103-84782001000100027

Sangoi, L., Almeida, M. L., Silva, P. R. F., \& Argenta, G. (2002). Bases morfofisiológicas para maior tolerância dos híbridos modernos de milho a altas densidades de plantas. Bragantia, 61(2), 101-110. doi: $10.1590 /$ S0006-87052002000200003

Sangoi, L., \& Salvador, R. J. (1996). Agronomic performance of male-sterile and fertile maize genotypes at two plant populations. Ciência Rural, 26(3), 377-383. doi: 10.1590/S010384781996000300006 
Sangoi, L., \& Salvador, R. J. (1998). Maize susceptibility drought at flowering: a new approach to overcome the problem. Ciência Rural, 28(4), 699-706. doi: $10.1590 / \mathrm{S} 0103-84781998000400027$

Santos, J. P., Pereira, I. A., Fº, \& Tomé, P. H. F. (2001). Colheita do minimilho. (Circular Técnica, 8). Sete Lagoas: EMBRAPA.
Singh, M. K., Singh, S. P., \& Singh, B. (2019). Agronomic Crops. In Mirza Hasanuzzaman, Agro-tecnhiques for baby corn production (pp. 261-272). Singapore: Springer Nature Singapore.

Vale, J. C., Fritsche, R., \& Silva, P. S. Neto. (2011). Índice de seleção para cultivares de milho com dupla aptidão: minimilho e milho verde. Bragantia, 70(4), 781-787. doi: 10.1590/S0006-87052011000400008 
